\title{
MOLECULAR DETECTION OF CLARITHROMYCIN AND FLUOROQUINOLONES RESISTANCE IN HELICOBACTER PYLORI INFECTION, DIRECTLY APPLIED TO GASTRIC BIOPSIES, IN AN URBAN BRAZILIAN POPULATION
}

\author{
Gustavo Miranda MARTINS, Bruno Squárcio Fernandes SANCHES, \\ Luciana Dias MORETZSOHN, Karine Sampaio LIMA, Bianca Della Croce V COTA and \\ Luiz Gonzaga Vaz COELHO
}

Received 8/12/2015

Accepted 1/2/2016

ABSTRACT - Background - Antimicrobial resistance is the major factor leading to eradication failure in $H$. pylori treatment. Molecular tests are useful to detect genetic mutations predictive of clarithromycin and fluoroquinolones resistance. Knowledge of the local prevalence rate of resistance is important to define the best recommended treatment. Objective - To assess the prevalence of primary resistance of $\mathrm{H}$. pylori to clarithromycin and fluoroquinolones, using a molecular test, in a Southeastern urban Brazilian population. Methods - A total of $72 \mathrm{H}$. pylori seropositive patients [65\% female, mean age 39 (19-73) years] never treated before for this infection were studied. All patients underwent gastroscopy in addition to antrum and corpus biopsies and molecular test GenoType HelicoDR (Hain Life Science, Germany) to detect H. pylori and point mutations in genes responsible for clarithromycin and fluoroquinolone resistance. The molecular procedure was divided into three steps: DNA extraction from biopsy samples, a multiplex amplification with biotinylated primers and a reverse hybridization. The most frequent point mutations involved in resistance to the two antibiotics were evaluated. Results - Resistance to clarithromycin was detected in nine $(12.5 \%)$ patients and to fluoroquinolones in eight (11.1\%) patients. The point mutation $\mathrm{A} 2147 \mathrm{G}$ was the most common $(77.8 \%)$ among resistant strains to clarithromycin. In $50 \%$ of the resistant strains to fluoroquinolones, the mutant codon couldn't be identified. Conclusion - The resistance rates to clarithromycin and fluorquinolones in a large urban population in the Southeast of Brazil were acceptable, suggesting that these drugs remain appropriate options to first and second-line of $H$. pylori treatment. The molecular test represents an adequate diagnostic tool for monitoring $H$. pylori resistance.

HEADINGS - Helicobacter pylori. Clarithromycin. Fluoroquinolones. Molecular pathology. Anti-infective agents.

\section{INTRODUCTION}

Helicobacter pylori (H. pylori) is the main cause of several gastroduodenal diseases, which are now considered as infectious disorders and treated with antibiotics. The gastritis induced by the infection is frequently subclinical but may evolve into chronic atrophic gastritis, gastroduodenal ulcer, gastric cancer and MALT lymphoma ${ }^{(4,18)}$. Triple therapy, including amoxicillin, clarithromycin and a proton pump inhibitor (PPI) given for a week has been recommended as the treatment of choice at several consensus conferences $^{(5,14,15,19)}$. Nevertheless, the efficacy of this regimen has been decreasing in the last years, with eradication rates lower than $80 \%$ in different studies ${ }^{(11,13,31)}$.
Antibiotic resistance is relevant if it leads to treatment failure. In $H$. pylori management, antimicrobial resistance is considered to be the major factor leading to eradication failure. The clinical impact of clarithromycin resistance is serious, since the efficacy decreases $70 \%$ if the strain is resistant in the context of PPI-clarithromycin-amoxicillin treatment ${ }^{(9,21)}$. The use of 10-day PPI-levofloxacin-amoxicillin has been recommended as an alternative second-line treatment $^{(5,19)}$. However, the acquisition of resistance may jeopardize its efficacy. Indeed, resistance to fluoroquinolones was also shown to be correlated to treatment failure of $H$. pylori ${ }^{(25,27)}$.

Studies have been performed to determine the prevalence of $H$. pylori resistance to antibiotics. 
In Europe, the resistance rate was $17.5 \%$ for clarithromycin and $14.1 \%$ for levofloxacin in patients never treated before for H. pylori (primary resistance) ${ }^{(22)}$. Apart from Europe, the prevalence of clarithromycin resistance has reached 10\%-15\% in the USA regardless of the region ${ }^{(7)}$. In Latin America, a systematic review demonstrated that the overall summary prevalences of resistance to clarithromycin was $12 \%$ and to fluoroquinolones $15 \%$ (2).

There are few regional studies in Brazil evaluating the prevalence of $H$. pylori resistance to clarithromycin and fluoroquinolones. Primary resistance to clarithromycin varied from $2.46 \%$ to $16.5 \%{ }^{(10,16,17,28,29)}$. Concerning fluoroquinolones, the $H$. pylori resistance rate was $5.5 \%$ in one study and $23 \%$ in another one ${ }^{(8,28)}$. However, only a small number of patients were enrolled in either study.

H. pylori resistance is essentially due to chromosomal mutations, and for the most part, a limited number of point mutations are present, which can be easily detected with molecular tests ${ }^{(23)}$. Such tests have been developed recently and allows the molecular detection of $H$. pylori and the genetic mutations predictive of resistance to clarithromycin (mutations in 23S-rRNA gene in positions 2146 and 2147) and to fluoroquinolones (mutations in gyrA gene, especially at codons 87 and 91$)^{(21,23,24,30)}$. The molecular test GenoType HelicoDR (Hain Life Science, Germany), which can be directly applied to gastric biopsies or in isolates obtained from culture, was evaluated in some European studies and was efficient at detecting mutations related to antibiotic resistance in $H$. pylori ${ }^{(3,6)}$.

The aim of this study was to assess the prevalence of clarithromycin and fluoroquinolones primary resistance in H. pylori directly from gastric biopsy specimens, using the molecular test GenoType HelicoDR, in a Southeastern urban Brazilian population.

\section{METHODS}

\section{Patients}

From October 2012 through July 2013, 72 patients resident in Belo Horizonte, a large city in the Southeast of Brazil, who had consecutively undergone diagnostic endoscopy with research of $H$. pylori due to abdominal symptoms, were enrolled in this study. Patients were selected from the Alfa Institute of Gastroenterology, Hospital of Clinics, Federal University of Minas Gerais, and had never been treated before for $H$. pylori infection. All of them were $H$. pylori positive by a rapid serological test (Abon Biopharm, Hangzhou, China) performed immediately before the endoscopy and previously validated among us ${ }^{(20)}$. Written informed consent was obtained prior to entering the study. The protocol was approved by the Ethical Committee in Human Research at the Federal University of Minas Gerais.

\section{Endoscopy and gastric biopsies}

Four gastric biopsies (two from the antrum, two from de corpus) were taken using Radial Jaw ${ }^{\mathrm{TM}} 4$ large capacity biopsy forceps (Boston Scientific, USA), which provides large tissue specimens for sample handling. The biopsies were immediately transferred to and immersed into micro-tubes containing RNAlater (Ambion, Cat.\#AM7020, USA), a solution that rapidly permeates the tissue to stabilize and protect cellular RNA. RNAlater minimizes the need to immediately process tissue samples. After an overnight period in the refrigerator at $4{ }^{\circ} \mathrm{C}$, the samples were weighted and finally frozen at $-80^{\circ} \mathrm{C}$ until the execution of molecular studies.

\section{Molecular diagnostic technique}

The molecular test GenoType HelicoDR was divided into three steps. Initially it was performed the DNA extraction from biopsy samples using the already validated QIAmp DNA Mini Kit (Qiagen, Benelux, The Netherlands). The next step was represented by a multiplex amplification with biotinylated primers. In order to check the amplification reaction, each sample was applied directly to a $2 \%$ agarose gel electrophoresis, which separated the biomolecules by length: $145 \mathrm{bp}$ (gyrA) and $100 \mathrm{bp}$ (23S RNA). The last phase of the molecular test was a reverse hybridization, that was performed using a specific incubator. The hybridization took place on strips that had been coated at the Hain Lifescience factory with different specific oligonucleotides (DNA probes) using the DNA strip technology. The probes were designed to hybridize with the sequences of the wild-type alleles or the mutated alleles in the tested sample. Results concerning H. pylori detection and susceptibility to clarithromycin and to fluoroquinolones were obtained by the analysis of the positive and negative bands in DNA strips. The most frequent mutations involved in resistance to the two antibiotics were also evaluated.

\section{Statistical analyses}

Techniques of descriptive statistics including measures of central tendency and variability were employed. An analysis was carried out to assess the risk factors associated with resistance to clarithromycin and fluoroquinolones. The odds ratio (OR) and the $95 \%$ confidence interval were used as estimates of the risk. $P<0.05$ was considered statistically significant. The Minitab 16 program was used.

\section{Ethical standards}

This study was approved by the research ethics committee of the Federal University of Minas Gerais (CAAE - 05004712.0.1001.5149) and was conducted in accordance with the Declaration of Helsinki of 1975, which was revised in 1983. All 72 patients agreed to participate in this study by reading and signing the Informed Consent Form that was approved by the same committee.

\section{RESULTS}

Seventy-two patients were included in this study. The age range was 19 to 73 years and mean age, 39 years. Fourty-seven $(65 \%)$ were females and $25(35 \%)$, males. Most common endoscopy findings were gastritis $(63.9 \%)$, gastric or duodenal ulcer $(22.2 \%)$, erosive esophagitis $(12.5 \%)$ and gastric cancer $(1.4 \%)$. 
$\chi 2$ test showed that gastritis was more common among women than men $(P=0.042)$.

Resistance to clarithromycin was detected in nine $(12.5 \%)$ samples. The most common $23 \mathrm{~S}$ gene mutation was A2147G, presented in seven $(77.8 \%)$ of the resistant strains, which predominated in relation to the mutation A2146G, observed in two $(22.2 \%)$ of the resistant strains. The point mutation A2146C was not found. The results of $H$. pylori antimicrobial resistance are presented in Table 1.

In six $(66.7 \%)$ of the clarithromycin-resistant cases, mixed H. pylori populations were found, combining both susceptible and resistant strains at the same sample. It could reflect coinfected cases or selection of resistant mutants.

A mutated gyrA genotype, leading to fluoroquinolones resistance, was observed in eight $(11.1 \%)$ samples: three $(37.5 \%)$ harboring mutation at codon 91 , one $(12.5 \%)$ with a mutation at codon 87 and four $(50 \%)$ cases with no mutant codon identified.

Resistance to the two classes of antibacterial agents at the same sample was found in only two $(2.8 \%)$ cases. On the other hand, as a whole, $79.2 \%$ of the strains did not show any resistance to the drugs tested.

There was no risk factor associated with resistance to clarithromycin or fluoroquinolones, nor to the two agents, among the studied variables (age, gender, endoscopy findings). The results of these analyses are presented in Tables 2 and 3.

TABLE 1. Prevalence of $H$. pylori antimicrobial resistance in the studied population

\begin{tabular}{lcc}
\hline Feature & Estimated value & 95\% Confidence Interval \\
\hline CLA susceptibility & $87.5 \%$ & 77.9 to $93.3 \%$ \\
CLA resistance & $12.5 \%$ & 6.7 to $22.1 \%$ \\
FQ susceptibility & $88.9 \%$ & 79.6 to $94.3 \%$ \\
$\begin{array}{l}\text { FQ resistance } \\
\text { CLA \& FQ }\end{array}$ & $11.1 \%$ & 5.7 to $20.4 \%$ \\
$\begin{array}{l}\text { susceptibility } \\
\text { CLA \& FQ } \\
\text { resistance }\end{array}$ & $79.2 \%$ & 68.4 to $86.9 \%$ \\
\hline
\end{tabular}

CLA: clarithromycin; FQ: fluoroquinolone.
TABLE 3. Association between risk factors and susceptibility or resistance to both clarithromycin and fluoroquinolones

\begin{tabular}{lll}
\hline Variable & $\begin{array}{c}\text { CLA \& FQ } \\
\text { susceptibility }\end{array}$ & $\begin{array}{c}\text { CLA \& FQ } \\
\text { resistance }\end{array}$ \\
\hline Age & OR $=2.32(\mathrm{NS})$ & $P=1.00^{*}(\mathrm{NS})$ \\
Gender & $\mathrm{OR}=1.60(\mathrm{NS})$ & $P=0.54^{*}(\mathrm{NS})$ \\
Gastritis & $\mathrm{OR}=0.21(\mathrm{NS})$ & $\mathrm{OR}=0.56(\mathrm{NS})$ \\
Ulcers & $\mathrm{OR}=2.17(\mathrm{NS})$ & $\mathrm{OR}=3.67(\mathrm{NS})$ \\
Esophagitis & $P=0.108 *(\mathrm{NS})$ & $P=1.00^{*}(\mathrm{NS})$ \\
\hline
\end{tabular}

CLA: clarithromycin; FQ: fluoroquinolone; OR: odds ratio; NS: not significant; *Fisher's exact test. $\alpha=0.05$.

\section{DISCUSSION}

This monocentric study analysed a convenience sample of $H$. pylori infected patients to assess the rate of primary resistance to clarithromycin and fluoroquinolones in a Brazilian Southeast city. Clarithromycin and fluoroquinolones are important drugs to treat $H$. pylori infection and resistance to them has been clearly associated with eradication failure. Because culture and susceptibility techniques are rarely done, the results obtained with the molecular methodology could be useful to review the strategies of antibiotic therapy.

Clarithromycin resistance is correlated with $23 \mathrm{~S}$ rRNA mutations (A2146G, A2146C, or A2147G) in more than 90\% of the clarithromycin-resistant strains ${ }^{(21)}$. In addition, fluoroquinolone resistance has been related to gyrA gene mutations at positions 87 and 91 in $80 \%$ to $100 \%$ of the fluoroquinoloneresistant strains ${ }^{(1,12,26)}$. In our study, the GenoType HelicoDR test presented as a rapid and feasible method to detect such mutations directly from gastric biopsies specimens.

The resistance rate to clarithromycin encountered by us $(12.5 \%)$ was close to those previously found in other Brazilian regional surveys ${ }^{(8,10,16,17,28)}$. Such rate was also almost similar to that demonstrated for Latin America in a recent published systematic review ${ }^{(2)}$ and lower than those detected in several Central and Southern European countries ${ }^{(22)}$.

TABLE 2. Association between risk factors and susceptibility or resistance to clarithromycin or fluoroquinolones

\begin{tabular}{lcccc}
\hline \multirow{2}{*}{ Variable } & \multicolumn{2}{c}{ Clarithromycin } & \multicolumn{2}{c}{ Fluoroquinolones } \\
\hline Age & CLA susceptibility & CLA resistance & FQ susceptibility & FQ resistance \\
Gender & $\mathrm{OR}=1.09(\mathrm{NS})$ & $\mathrm{OR}=0.91(\mathrm{NS})$ & $P=0.185^{*}(\mathrm{NS})$ & $P=0.185 *(\mathrm{NS})$ \\
Gastritis & $\mathrm{OR}=2.01(\mathrm{NS})$ & $\mathrm{OR}=0.50(\mathrm{NS})$ & $\mathrm{OR}=1.68(\mathrm{NS})$ & $\mathrm{OR}=0.59(\mathrm{NS})$ \\
Ulcers & $\mathrm{OR}=0.46(\mathrm{NS})$ & $\mathrm{OR}=2.15(\mathrm{NS})$ & $\mathrm{OR}=0.22(\mathrm{NS})$ & $\mathrm{OR}=4.49(\mathrm{NS})$ \\
Esophagitis & $\mathrm{OR}=1.00(\mathrm{NS})$ & $\mathrm{OR}=1.00(\mathrm{NS})$ & $\mathrm{OR}=2.14(\mathrm{NS})$ & $\mathrm{OR}=0.46(\mathrm{NS})$ \\
\hline
\end{tabular}

CLA: clarithromycin; FQ: fluoroquinolone; OR: odds ratio; NS: not significant; *Fisher's exact test. $\alpha=0.05$. 
The distribution of mutations involved in resistance to clarithromycin was comparable to the results of some European and Brazilian previous reports, being the point mutation $\mathrm{A} 2147 \mathrm{G}$ the most frequent $\mathrm{t}^{(3,6,16)}$. The overall frequency of mixed $\mathrm{H}$. pylori populations $(66.7 \%)$ at the same sample was higher than that established in some regional European studies $^{(3,6)}$.

Resistance to fluoroquinolones was detected in $11.1 \%$ of samples. Our results are in an intermediate level between those previously verified in two regional Brazilian studies ${ }^{(8,28)}$ and are close to the recently found in Europe ${ }^{(22)}$ and reviewed in Latin America ${ }^{(2)}$. A mutant codon wasn't identified in 50\% of the fluoroquinolone-resistant cases. This rate is higher than that mentioned in a French survey ${ }^{(3)}$. In these cases, former studies using sequencing showed a mutation in gyrA gene that was not specifically present on the DNA strip of the test. The reasons for this high occurence of distinct mutations leading to fluoroquinolones resistance in the studied population are still unknown. Finally, resistance to both clarithromycin and fluoroquinolones at the same sample was uncommon $(2.8 \%)$.

Similar to most of the studies performed to determine the prevalence of $H$. pylori resistance to antibiotics, the data we summarized have some disadvantages, especially regarding the number and representativeness of the strains tested. Patients were recruited in a single specialized medical center and may not be representative of the appropriate target population. Moreover, a not random sampling doesn't allow steady conclusions to be drawn for the general population.

In conclusion, this is the first time that such a study has been carried out in Brazil, evaluating the usefulness of a standard molecular method to ascertain the presence of resistance of $H$. pylori to the antibiotics, on the basis of samples obtained directly from gastric biopsies. The molecular test GenoType HelicoDR is easily implemented in our daily practice, representing an adequate diagnostic tool for monitoring $H$. pylori resistance.

The resistance rates to clarithromycin and fluorquinolones in a large population in the Southeast of Brazil were considered acceptable, suggesting that these drugs remain appropriated options to first and second line of $H$. pylori treatment. Our study emphasizes the need of national surveys to evaluate and monitor $H$. pylori resistance to antibiotics, in order to optimize the effectiveness of anti- $H$. pylori treatment.

\section{Authors' contributions}

Martins GM: data collection; lab research; statistical analysis; discussion of the results; text edition. Sanches BSF: data collection; statistical analysis; discussion of the results. Moretzsohn LD: data collection; discussion of the results. Lima KS: lab research; discussion of the results. Cota BDCV: lab research; discussion of the results. Coelho LGV: contribution the basic idea for the whole project; outline the research; text edition.

Martins GM, Sanches BSF, Moretzsohn LD, Lima KS, Cota BDCV, Coelho LGV. Detecção molecular de resistência do Helicobacter pylori à claritromicina e fluorquinolonas, diretamente a partir de biópsias gástricas, em uma capital Brasileira. Arq Gastroenterol. 2016,53(2): 113-7.

RESUMO - Contexto - A resistência aos antimicrobianos é o principal fator associado à falha terapêutica no tratamento do $H$. pylori. Testes moleculares são úteis na detecção das mutações genéticas associadas ao desenvolvimento de resistência à claritromicina e fluorquinolonas. O conhecimento da taxa de prevalência local de resistência é importante na definição do melhor esquema terapêutico. Objetivo - Estimar a prevalência de resistência primária do H. pylori à claritromicina e fluorquinolonas, empregando-se um teste molecular, em uma capital do Sudeste do Brasil. Métodos - Setenta e dois pacientes com sorologia positiva para H. pylori [65\% mulheres, idade média 39 (19-73) anos], nunca tratados previamente para essa infecção, foram selecionados. Todos os pacientes submeteram-se à endoscopia digestiva com biópsias de antro e corpo e realização do teste molecular GenoType HelicoDR (Hain Life Science, Alemanha) para a detecção do H. pylori e das mutações pontuais dos genes responsáveis pela resistência à claritromicina e fluorquinolonas. O procedimento molecular constituía-se de três etapas: extração do DNA a partir das amostras endoscópicas, amplificação multiplex com primers biotinilados e hibridização reversa. As mutações pontuais mais frequentemente envolvidas com resistência aos dois antibióticos foram avaliadas. Resultados - Resistência à claritromicina foi detectada em nove (12,5\%) pacientes e às fluorquinolonas em oito (11,1\%) pacientes. A mutação pontual $\mathrm{A} 2147 \mathrm{G}$ foi a mais comum $(77,8 \%)$ entre as cepas resistentes à claritromicina. Em $50 \%$ das cepas resistentes à fluorquinolonas, o códon mutante não pôde ser identificado. Conclusão - As taxas de resistência à claritromicina (12,5\%) e às fluorquinolonas (11,1\%), em uma importante capital do Sudeste do Brasil, mostraram índices aceitáveis, sugerindo que essas drogas permanecem opções apropriadas para o tratamento de primeira e segunda linha do H. pylori. O teste molecular constitui uma ferramenta diagnóstica adequada para monitorar a resistência do $H$. pylori.

DESCRITORES - Helicobacter pylori. Claritromicina. Fluoroquinolonas. Patologia molecular. Anti-infecciosos. 


\section{REFERENCES}

1. Bogaerts P, Berhin C, Nizet H, Glupcznski Y. Prevalence and mechanisms of resistance to fluoroquinolones in Helicobacter pylori strains from patients living in Belgium. Helicobacter. 2006;11:441-5.

2. Camargo MC, Garcia A, Riquelme A, Otero W, Camargo CA, Hernandez-Garcia T, et al. The problem of Helicobacter pylori resistance to antibiotics: a systematic review in Latin America. Am J Gastroenterol. 2014;109:485-95.

3. Cambau E, Allerheiligen V, Coulon C, Corbel C, Lascols C, Deforges L, et al. Evaluation of a new test, Genotype HelicoDR, for molecular detection of antibiotic resistance in Helicobacter pylori. J Clin Microbiol. 2009;47:3600-7.

4. Chey WD, Wong BC. American College of Gastroenterology guideline on the management of Helicobacter pylori infection. Am J Gastroenterol. 2007; 102:1808-25.

5. Coelho LG, Maguinilk I, Zaterka S, Parente JM, Passos MC, Moraes-Filho JPP. $3^{\text {rd }}$ Brazilian Consensus on Helicobacter pylori. Arq Gastroenterol. 2013;50:81-96.

6. Deyi VY, Burette A, Bentatou Z, Maaroufi Y, Bontems P, Lepage P, et al. Practical use of Genotype HelicoDR, a molecular test for Helicobacter pylori detection and susceptibility testing. Diag Microbiol Infect Dis. 2011;70:557-60.

7. Duck WM, Sobel J, Pruckler JM, Song Q, Swerdlow D, Friedman C, et al Antimicrobial resistance incidence and risk factors among Helicobacter pylo$r i$-infected persons, United States. Emerg Infect Dis. 2004;10:1088-94

8. Eisig JN, Silva FM, Barbuti RC, Navarro-Rodrigues T, Moraes-Filho JPP, Pedrazzoli Jr J. Helicobacter pylori antibiotic resistance in Brazil: clarithromycin is still a good option. Arq Gastroenterol. 2011;48:261-4.

9. Fischbach L, Evans EL. Meta-analysis: the effect of antibiotic resistance status on the efficacy of triple and quadruple first-line therapies for Helicobacter pylori. Aliment Pharmacol Ther. 2007;26:343-57.

10. Godoy AP, Ribeiro ML, Benvengo YH, Vitiello L, Miranda MC, Mendonça $\mathrm{S}$, et al. Analysis of antimicrobial susceptibility and virulence factors in Helicobacter pylori clinical isolates. BMC Gastroenterol. 2003;3:20-5.

11. Janssen MJ, Van Oijen AH, Verbeek AL, Jansen JB, De Boer WA. A systematic comparison of triple therapies for treatment of Helicobacter pylori infection with proton pump inhibitor/ranitidine bismuth citrate plus clarithromycin and either amoxicillin or a nitroimidazole. Aliment Pharmacol Ther. 2001;15:613-24

12. Kim JM, Kim JS, Kim N, Jung HC, Song IS. Distribution of fluoroquinolone MICs in Helicobacter pylori strains from Korean patients. J Antimicrob Chemother. 2005;56:965-7.

13. Laheij RJ, Rossum LG, Jansen JB, Straatman H, Verbeek AL. Evaluation of treatment regimens to cure Helicobacter pylori infection - a meta-analysis. Aliment Pharmacol Ther. 1999;13:857-64.

14. Lamouliatte HC, Cayla R, Megraud F, Zerbib F, Stablo M, Bouchard S, et al. Amoxicillin-clarithromycin-omeprazole: the best therapy for Helicobacter pylori infection. Acta Gastroenterol Belg. 1993;56:A140.

15. Lind T, Megraud F, Unge P, Bayerdorffer E, O'Morain C, Spiller R, et al. The MACH2 study: role of omeprazol in eradications of Helicobacter pylori with 1-week triple therapies. Gastroenterology. 1999;116:248-53.
16. Lins AK, Lima RA, Magalhães M. Clarithromycin-resistant Helicobacter pylor in Recife, Brazil, directly identified from gastric biopsies by polymerase chain reaction. Arq Gastroenterol. 2010;47:379-82.

17. Magalhães PP, Queiroz DM, Barbosa DV, Rocha GA, Mendes EN, Santos A, et al. Helicobacter pylori primary resistance to metronidazol and clarithromycin in Brazil. Antimicrob Agents Chemother. 2002;46:2021-3.

18. Malfertheiner P, Megraud F, O'Morain C, Bazzoli F, El-Omar E, Graham D, et al. Current concepts in the management of Helicobacter pylori infection: the Maastricht III Consensus Report. Gut 2007;56:772-81.

19. Malfertheiner P, Megraud F, O'Morain CA, Atherton J, Axon ATR, Bazzoli F, et al. Management of Helicobacter pylori infection - the Maastricht IV/Florence Consensus Report. Gut. 2012;61:646-64.

20. Martins GM, Sanches BSF, Moretzsohn LD, Coelho LG. Rapid in-office H. pylori serologic test: an useful tool in areas with high $H$. pylori prevalence? [Abstract] In: European Helicobacter Study Group: XXVIth International Workshop on Helicobacter and Related Bacteria in Chronic Digestive Inflammation and Gastric Cancer; 2013; Madrid, Spain. Helicobacter. 2013;18:120.

21. Megraud F. H pylori antibiotic resistance: prevalence, importance, and advances in testing. Gut. 2004;53:1374-84.

22. Megraud F, Coenen S, Versporten A, Kist M, Lopez-Brea M, Hirschl AM, et al. Helicobacter pylori resistance to antibiotics in Europe and its relationship to antibiotic consumption. Gut. 2013;62:34-42.

23. Megraud F, Lehours P. Helicobacter pylori detection and antimicrobial susceptibility testing. Clin Microbiol Rev. 2007;20:280-322.

24. Moore RA, Beckthold B, Wong S, Kureishi A, Bryan LE. Nucleotide sequence of the gyrA gene and characterization of ciprofloxacin resistant mutants of Helicobacter pylori. Antimicrob Agents Chemother. 1995;39:107-11.

25. Nishizawa T, Suzuki H, Kurabayashi K, Masaoka T, Muraoka H, Mori M, et al. Gatifloxacin resistance and mutations in gyrA after unsuccessful Helicobacter pylori eradication in Japan. Antimicrob Agents Chemother. 2006;50:1538-40.

26. Nishizawa T, Suzuki H, Umezawa A, Muraoka H, Iwasaki E, Masaoka T, et al. Rapid detection of point mutations conferring resistance to fluoroquinolone in gyrA of Helicobacter pylori by allele-specific PCR. J Clin Microbiol. 2007;45:303-5.

27. Perna F, Zulbo A, Ricci C, Hassan C, Morini S, Vaira D. Levofloxacina-based triple therapy for Helicobacter pylori retreatment: Role of bacterial resistance. Dig Liver Dis. 2007:39:1001-5.

28. Picoli SU, Mazzoleni LE, Fernández H, De Bona LR, Neuhauss E, Longo L, et al. Resistance to amoxicillin, clarithromycin and ciprofloxacin of Helicobacter pylori isolated from Southern Brazil patients. Rev Inst Med Trop Sao Paulo. 2014;56:197-200

29. Suzuki RB, Lopes RA, Lopes GA, Ho TH, Sperança MA. Low Helicobacter pylori primary resistance to clarithromycin in gastric biopsy specimens from dyspeptic patients of a city in the interior of São Paulo, Brazil. BMC Gastroenterol. 2013;13:164

30. Tankovic J, Lascols C, Sculo Q, Petit JC, Soussy CJ. Single and double mutations in gyr A but not in gyr B are associated with low and high-level fluorquinolone resistance in Helicobacter pylori. Antimicrob Agents Chemother. 2003;47:3942-4.

31. Vakil N, Lanza F, Schwartz H, Barth J. Seven-day therapy for Helicobacter pylori in the United States. Aliment Pharmacol Ther. 2004;20:99-107. 